\title{
Produksi dan Kualitas Jamur Merang (Volvariella volvaceae) pada Kelompok Tani "Mitra Usaha" Kabupaten Karawang
}

\section{Production and Quality Straw Mushroom (Volvariella volvaceae) in Farmers Group "Mitra Usaha" at Karawang District}

\author{
Faisal Radjab Munawar dan Juang Gema Kartika²
}

Departemen Agronomi dan Hortikultura, Fakultas Pertanian, Institut Pertanian Bogor, Jalan Meranti,
Kampus IPB Darmaga, Bogor 16680, Indonesia
Telp.\&Faks. 62-251-8629353 e-mail agronipb@ indo.net.id
*Penulis untuk korespondensi : ika_juang@yahoo.com

Disetujui 17 Mei 2017/Published online 22 Mei 2017

\begin{abstract}
Research conducted Farmer Group Mitra Usaha, Panyingkiran Village, Karawang from February 9th until June 8th 2015. The internship activities carried out to gain experience and knowledge in production of Merang mushroom, along to analyze the business feasibility in farmer group Mitra Usaha Karawang. The medium which is used in one production cycle of Straw mushroom namely straw, cotton, rice bran, and lime. The production process includes composting of straw and cotton, sterilization, stocking seeds, watering, harvesting and post-harvest. Straw mushroom may be harvested from the nine day after the stocking of seedlings or five days after watering. The harvest is done by each day during 20-25 days. The Farmer Group Mitra Usaha have 12 mushrooms house (kumbung), with the average production of every mushroom house about $200 \mathrm{~kg} / \mathrm{kumbung}$ of mushrooms in one production cycle for at least 1.5 months. The results of the analysis of farm production for straw mushroom, the farmer group Mitra Usaha has $R / C$ ratio value of more than 1 (1.91), which is means that the farmer group Mitra Usaha feasible to continue run the production. Analysis of farming uses the assumption that production in one mushroom house is $200 \mathrm{~kg} / \mathrm{kumbung}$, the price of mushrooms Rp22 000,00/kg. BEP (Break Event Point) prices earned Rp11 536,00 and BEP production volume amounted to $105 \mathrm{~kg}$.
\end{abstract}

Keywords: Mushrooms, Straw, Production.

\section{ABSTRAK}

Penelitian dilaksanakan di Kelompok tani Mitra Usaha, Desa Panyingkiran, Kabupaten Karawang dari 9 Februari hingga 8 Juni 2015. Kegiatan penelitian dilaksanakan untuk meperoleh pengalaman dan pengetahuan dalam produksi jamur merang, serta menganalisis kelayakan usaha pada kelompok tani Mitra Usaha Karawang. Media yang digunakan dalam produksi jamur merang yaitu jerami, kapas, dedak, dan kapur. Proses produksi meliputi pengomposan jerami dan kapas, pasteurisasi, penebaran bibit, penyiraman, panen dan pasca panen. Jamur merang dapat dipanen sejak 9 hari setelah penebaran bibit atau 5 hari setelah penyiraman. Panen dilakukan setiap hari selama 20-25 hari. Kelompok tani Mitra Usaha memiliki 12 kumbung jamur, dengan rata - rata setiap kumbung mampu menghasilkan 200 kg/kumbung jamur dalam satu siklus produksi selama kurang lebih 1.5 bulan. Hasil analisis usaha tani produksi jamur merang, kelompok tani Mitra Usaha memiliki nilai $R / C$ rasio lebih dari 1 yaitu 1.91, sehingga layak untuk terus berproduksi. Analisis usaha tani menggunakan asumsi produksi jamur satu kumbung adalah $200 \mathrm{~kg}$ per kumbung, harga jamur Rp22 000,00 per kg. BEP (Break Event Point) untuk harga didapatkan sebesar Rp11 536,00 dan BEP volume produksi sebesar $105 \mathrm{~kg}$.

Kata kunci : jamur, merang, produksi 


\section{PENDAHULUAN}

Jamur merang segar memiliki kandungan gizi yang tinggi. Protein yang terkandung dalam jamur merang segar sebanyak $1.8 \%$. Protein pada jamur merang segar lebih besar dibandingkan dengan sayuran lain seperti kubis, wortel dan tomat dalam bentuk segar (Agromedia, 2009).

Tingginya permintaan konsumen terhadap komoditas jamur belum dapat diimbangi dengan tingkat produksinya. Produksi jamur di Indonesia pada tahun 2011 sampai 2014 cenderung fluktuatif, pada tahun 2011 produksi jamur di Indonesia sebanyak 45854 ton, tahun 2012 menurun menjadi 40886 ton, tahun 2013 meningkat kembali menjadi 44565 ton dan pada tahun 2014 menurun mejadi $37 \quad 410$ ton (Kementan, 2015a). Tingkat konsumsi masyarakat Indonesia terhadap jamur 2 tahun terakhir mengalami peningkatan. Menurut data dari Kementan (2015b), konsumsi jamur perkapita di Indonesia dari tahun 2013 ke 2014 mengalami peningkatan sekitar 300 gram, sehingga dengan asumsi \pm 250 juta penduduk dikalikan 300 gram menjadi 75000 ton perkapita pertahun. Peningkatan konsumsi masyarakat tidak sebanding dengan produksi yang fluktuatif sehingga diperlukan peningkatan produksi jamur.

Kurangnya produksi dalam negeri membudidayakan jamur. Budidaya jamur konsumsi di Indonesia tersebar di berbagai wilayah. Provinsi penghasil jamur terbesar adalah Jawa Barat. Tahun 2013 produksi jamur di Jawa Barat mencapai 32683 ton. Hasil tersebut menjadikan Jawa Barat sebagai penghasil jamur terbesar di Indonesia (Kementan, 2015c). Produksi jamur di Kabupaten Karawang pada tahun 2013 sebanyak 16619 ton atau sebanyak $50.84 \%$ dari total produksi di provinsi Jawa Barat (Kementan, 2015d).

Produksi yang tinggi menjadikan Kabupaten Karawang sebagai sentra produksi jamur di Indonesia. Salah satu jamur konsumsi yang dibudidayakan di karawang adalah jamur merang. Jamur merang banyak di budidayakan karena mempunyai siklus hidup yang pendek yakni kurang lebih satu bulan, sehingga sangat mudah untuk dibudidayakan. Selain itu, jamur merang memiliki rasa dan tekstur baik sehingga disukai masyarakat (Sinaga, 2012). Menurut data Masyarakat Agribisnis Jamur Indonesia (MAJI) produksi jamur merang mendominasi 55-60\% dari total produksi jamur nasional (Agrina, 2007). Jamur merang membutuhkan suhu sekitar 30 $36^{\circ} \mathrm{C}$, kelembaban $75 \%$ - $80 \%$ dan intensitas cahaya $5-10 \%$ (Trubus, 2012).
Budidaya jamur merang memerlukan tahapan-tahapan yang harus dilakukan yaitu pembuatan kumbung, fermentasi untuk media tumbuh, pembuatan pembangkit uap, pengisian media serta pasteurisasi, penyiraman, proses pemeliharaan, pengendalian OPT, panen dan pasca panen. Cara budidaya jamur merang harus dilakukan dengan baik guna menghasilkan jamur yang berkualitas. Pemilihan media tanam sangat berpengaruh terhadap pertumbuhan jamur. Menurut Zuyasna, Nasution dan Fitriani (2011), media tanam berpengaruh sangat nyata terhadap berat buah dan diameter tudung. Semakin baik media yang digunakan makan semakin baik pula pertumbuhan jamur yang dihasilkan. Jamur merang umumnya tumbuh pada media yang merupakan sumber selulosa seperti tumpukan merang, limbah pabrik kertas, dan limbah kelapa sawit (Sinaga, 2012). Selain media tanam, kelembaban juga menjadi salah satu faktor yang mempengaruhi pertumbuhan jamur merang.

Banyaknya manfaat dari jamur merang serta telah diketahui bahwa Karawang merupakan sentra produksi jamur merang di Indonesia, menjadi latarbelakang pemilihan kegiatan penelitian di kelompok tani Mitra Usaha di Kabupaten Karawang dilakukan. Adapun maksud dilaksanakannya kegiatan penelitian di kelompok tani "Mitra Usaha", Kabupaten Karawang yaitu untuk mempelajari segala kegiatan yang bersangkutan dengan produksi dan kualitas jamur merang serta menganalisa kelayakan usaha jamur merang di kelompok tani "Mitra Usaha".

\section{BAHAN DAN METODE}

Kegiatan penelitian dilaksanakan di kelompok Tani Mitra Usaha, Dusun Krajan 1 Rt 01/01, Desa Panyingkiran, Kecamatan Rawamerta, Kabupaten Karawang. Kegiatan Penelitian dilaksanakan pada bulan Februari sampai Juni 2015.

Metode pelaksanaan yang dilakukan meliputi kegiatan budidaya jamur (persiapan media, penanaman, perawatan, panen, pasca panen), pemasaran, pengamatan pertumbuhan tanaman.

Hal lain yang dilaksanakan adalah melakukan analisis informasi yang diperoleh. Bentuk kegiatanyang dilakukan pada saat penelitian adalah orientasi lapangan. Kegiatan orientasi lapang dilakukan untuk mengetahui keadaan umum perusahaan seperti profil perusahaan, tata areal dan sistem kerja yang diterapkan dan juga sebagai ajang perkenalan dengan para staf untuk mengetahui permasalahan yang ada di perusahaan. Kegiatan selanjutnya 
yaitu bekerja sebagai karyawan produksi. Kegiatan selanjutnya sebagai pendamping manajer (Ketua kelompok tani). Kegiatan yang dilakukan sebagai pendamping manajer antara lain membantu kegiatan di lapangan dan mempelajari sistem manajerial tingkat lapang dimana bisa mempelajari tentang pembuatan jadwal tanam dan bagaimana caranya agar dapat berproduksi berkelanjutan.

Proses pengumpulan data dan informasi yang dilakukan berupa pengumpulan data primer dan sekunder. Data primer diperoleh dari hasil pengamatan langsung di lapang berupa data yang berkaitan dengan aspek produksi, yang terdiri atas: data pembibitan, pemeliharaan dan pertumbuhan tanaman, panen dan pasca panen hingga pemasaran hasil dan juga kegiatan wawancara dan diskusi dengan manajer dan karyawan. Data sekunder didapat dari arsip dan studi literatur perusahaan berupa produktivitas, kondisi perusahaan, bangunan tanam, tenaga kerja dan data-data lain yang mendukung. Metode yang digunakan dalam pengumpulan data baik primer maupun data sekunder antara lain: mengikuti secara langsung kegiatan persiapan, produksi, dan pasca panen hingga pemasaran jamur merang, wawancara dengan staf dan pekerja kelompok Tani Mitra Usaha selama penelitian berlangsung, mengumpulkan data mengenai produksi, baik data dari pengamatan yang dilakukan maupun data dari perusahaan, melakukan studi pustaka yang berkaitan dengan budidaya jamur merang.

Beberapa pengamatan yang dilakukan berkenaan dengan aspek produksi dan kualitas hasil jamur merang adalah profil perusahaan (letak geografis dan administratif kelompok tani, keadaan iklim dan tanah, struktur organisasi dan ketenagakerjaan kelompok tani), budidaya (media yang digunakan, campuran bahan untuk media, bibit yang digunakan, pemeliharaan jamur merang, panen dan pasca panen), produksi kualitas hasil (mengambil sampel 500 gram setiap rak dan pisahkan jamur super dan bekas super (BS)), pemasaran, analisi usaha tani, analisis permasalahan, dan studi pustaka.

Data yang diperoleh dan dikumpulkan dari kegiatan penelitian berupa data primer dan sekunder. Data, diolah dengan menggunakan analisis kuantitatif dan analisis deskriptif. Analisis kuantitatif dilakukan pada data primer dan sekunder yang bersifat kuantitatif dengan menggunakan persentase dan juga uji-t student, sedangkan data yang bersifat kualitatif dianalisis dengan menggunakan analisis deskriptif.

\section{HASIL DAN PEMBAHASAN}

\section{Kondisi Umum}

Kelompok tani Mitra Usaha merupakan gabungan para petani yang terdapat di Desa Panyingkiran. Desa Panyingkiran berada di Kecamatan Rawamerta, Kabupaten Karawang, Provinsi Jawa Barat. Desa Panyingkiran berada pada ketinggian 12 mdpl (Data Desa).

Keadaan iklim sesuai dengan datarannya yang rendah memilik temperatur udara rata - rata $27^{\circ} \mathrm{C}$. Curah hujan rata - rata tiap tahun $1000-$ $2000 \mathrm{~mm}$. Jenis tanah menurut klassifikasi umum adalah Aluvial dengan tekstur liat.

Jamur merang merupakan tanaman hortikultura yang mulai banyak digemari masyarakat Indonesia dan mulai banyak dibudidayakan. Jamur merang dapat tumbuh pada suhu $30^{\circ} \mathrm{C}-35^{\circ} \mathrm{C}$ dengan kelembaban $80-90 \%$. Jamur juga membutuhkan sinar matahari yang cukup, tetapi tidak dipancarkan secara langsung (Agromedia, 2009). Jamur merang biasanya tumbuh didataran rendah, karena suhu pada dataran rendah yang cukup tinggi disbanding dataran tinggi. Kabupaten Karawang memiliki rata - rata suhu tahunan $27.1{ }^{\circ} \mathrm{C}$ dengan curah hujan $1.823 \mathrm{~mm} /$ tahun (Climate-data, 2015).

\section{Persiapan alat dan bahan}

Jamur merang merupakan salah satu jenis jamur yang banyak dibudidayakan masyarakat Indonesia terutama daerah dataran rendah seperti Kabupaten Karawang. Salah satu syarat untuk budidaya jamur merang adalah membuat kumbung atau rumah jamur. Kelompok tani "Mitra Usaha" membuat kumbung dengan ukuran panjang $6 \mathrm{~m}$, lebar $4 \mathrm{~m}$, dan tinggi $4 \mathrm{~m}$. Kumbung terdiri dari 2 ruang yaitu bagian dalam dan bagian luar. Pada bagian dalam kumbung terdapat rak yang terdiri dari 5 tingkat rak sebelah kiri dan 5 tingkat rak disebelah kanan. Bagian bawah atau lantai pada bagian dalam biasanya di semen agar mudah membersihkannya, sedangkan lantai pada bagian luar dibiarkan tanah.

Pembangkit uap adalah alat yang digunakan untuk proses sterilisaasi kumbung jamur sebelum ditanami bibit jamur. Pembangkit uap terbuat dari drum berukuran 200 liter yang disambungkan dengan pipa besi dan paralon ke dalam kumbung. Menurut Sinaga (2012), satu tangki berisi air 200 liter, cukup untuk memberikan uap panas dalam kumbung berukuran $4 \mathrm{~m} \times 6 \mathrm{~m} \times 2.5 \mathrm{~m}$.

Pemilihan media tanam yang digunakan akan mempengaruhi hasil yang didapat. Media 
tanam berpengaruh nyata pada waktu panen pertama, periode panen, panjang badan buah, diameter buah dan hasil berat basah segar buah (Mayun, 2007). Menurut Yuliani (2009) media yang sangat baik digunakan sebagai media tumbuh jamur merang adalah blotong (baik diaplikasikan secara tunggal maupun dicampur dengan media lain). Media tanam yang digunakan kelompok tani ini yaitu jerami padi dengan bahan tambahan yaitu kapas, kapur, dedek halus.

Jerami yang biasa digunakan para petani adalah jerami yang dihasilkan dari hasil panen padi yang digebot atau dengan cara konvensional bukan yang dipanen menggunakan mesin pemanen. Menurut Pak Bahri sebagai ketua kelompok tani tersebut mengatakan, dengan sistem panen digebot jerami yang dihasilkan masih utuh sehingga waktu terdekomposisi jerami lebih lama sebagai pemberi makanan pada masa pertumbuhan jamur merang, sedangkan jerami yang didapat dari hasil panen padi yang menggunakan mesin cederung sudah tercacah sehingga jerami tidak dapat bertahan lama. Untuk satu kumbung berukuran $6 \mathrm{~m}$ x $4 \mathrm{~m}$ x $4 \mathrm{~m}$ diperlukan 250 ikat jerami. Jerami didapatkan petani jamur dibeli dari para petani sawah dengan harga Rp3 000,00 /ikat dengan ukuran setiap ikat sekitar $3 \mathrm{~kg}$.

Kapas yang digunakan kelompok tani yaitu dari limbah pabrik tekstil di daerah Bandung. Para anggota membeli kapas kepada pengepul dan dibayar ketika panen. Kapas dijual pengepul dengan harga Rp1 000,00/kg. Kapas yang dibutuhkan dalam sekali produksi sebanyak $300 \mathrm{~kg}$. Kapas digunakan sebagai campuran media tanam. Dedak yang digunakan untuk budidaya jamur yaitu dedak halus. Penggunaan dedak halus pada kegiatan usahatani jamur merang berfungsi untuk menambah asupan nutrisi pada media tanam jamur merang. Penggunaan dedak halus sebagai hara tambahan tidak hanya menyebabkan produksi meningkat namun laju pelapukan selulosa jerami lebih rendah serta membuat jumlah periode panen semakin panjang (Oktaviana 2013). Petani membeli dedak halus dengan harga Rp10 000,00/kg. Dedak yang dibutuhkan untuk sekali produksi sebanyak $10 \mathrm{~kg}$.

Kapur yang dibutuhkan untuk sekali produksi sebanyak $5 \mathrm{~kg}$ dengan harga Rp10 000,00/kg. Kapur digunakan sebagi bahan campuran media jerami dan kapas pada saat proses fermentasi. Bibit jamur merang yang digunakan oleh kelompok tani yaitu bibit yang sudah siap ditanam dalam kumbung. Bibit disediakan oleh pengepul dengan harga Rp3 $500,00 / \log$. Bibit yang dibutuhkan dalam sekali produksi sebanyak 70 log. Proses produksi jamur merang melalui beberapa tahap yaitu, fermentasi, pengisian media, pasteurisasi, persiapan dan penanaman bibit, perawatan, panen, dan pasca panen.

\section{Produksi}

Jamur merang memiliki pertumbuhan yang cukup cepat. Waktu pemanenan mempengaruhi hasil yang didapat baik dalam jumlah yang didapat maupun kualitas. Data yang diambil terbagi menjadi dua yaitu bobot panen harian jamur per kumbung dan bobot panen harian jamur merang yang diambil sampel 500 gram per rak. Data dikumpulkan dari 4 kumbung yang berbeda (4 ulangan).

Berdasarkan data dari keempat kumbung tersebut, dapat diketahui bahwa kumbung 3 mengalami gagal panen. Produksi yang seharusnya berlangsung selama 20 - 25 hari hanya berlangsung selama 4 hari. Panen yang didapat dari kumbung 3 sebesar $13 \mathrm{~kg}$ jamur super dan 1.4 $\mathrm{kg}$ jamur BS. Kumbung 1 memiliki masa panen paling lama yang mencapai 23 hari, sedangkan kumbung 2 dan kumbung 4 mencapai 21 hari. Kumbung 3 tidak digunakan sebagai data karena mengalami gagal panen. 


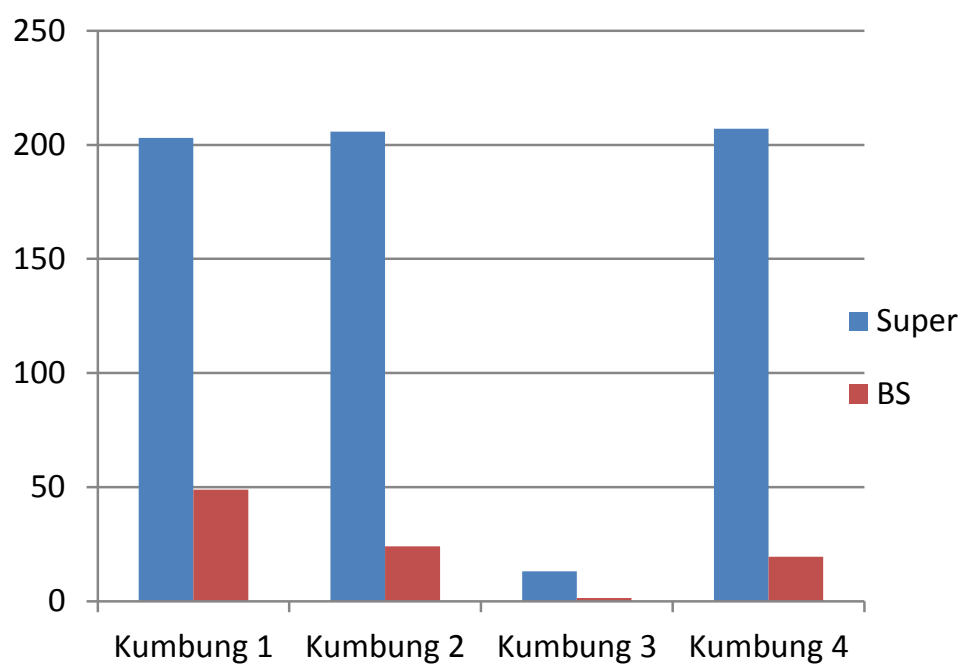

Gambar 1. Bobot hasil panen yang diperoleh 4 kumbung selama satu siklus produksi

Data bobot panen harian jamur merang perkumbung.

Masa panen yang lebih lama menjadikan kumbung 1 memiliki hasil panen yang lebih banyak dibanding 3 kumbung lainnya. Kumbung 1 dengan 23 hari masa panen mendapatkan hasil sebanyak $251.9 \mathrm{~kg}$ jamur merang dengan masing - masing $203 \mathrm{~kg}$ jamur super dan $48.9 \mathrm{~kg}$ jamur BS. Kumbung 3 dengan masa panen 21 hari mendapatkan hasil sebanyak $229.9 \mathrm{~kg}$ jamur merang yaitu $205.8 \mathrm{~kg}$ jamur super dan $24.1 \mathrm{~kg}$ jamur BS. Hasil yang didapatkan kumbung 4 dengan masa panen 21 hari sebanyak $226.5 \mathrm{~kg}$ jamur merang yaitu sebanyak $207.1 \mathrm{~kg}$ jamur super dan 19.4 jamur BS. Berdasarkan data tersebut, masa panen jamur merang mempengaruhi hasil panen yang diperoleh jamur merang yaitu sebanyak $207.1 \mathrm{~kg}$ jamur super dan 19.4 jamur BS. Berdasarkan data tersebut, masa panen jamur merang mempengaruhi hasil panen yang diperoleh.

Tabel 2 adalah rata - rata bobot panen dari keempat kumbung. Data hari pertama sampai hari ke 21 adalah rata - rata dari 3 kumbung yaitu kumbung 1, 2, dan 4. Hari ke 22 dan 23 hanya didapat dari kumbung 1. Hasil tersebut menunjukan bahwa rata - rata setiap kumbung dengan ukuran $6 \mathrm{~m}$ x $4 \mathrm{~m} \mathrm{x} 4 \mathrm{~m}$ dengan jumlah rak masing - masing kumbung 10 mampu memproduksi jamur sebanyak $237.42 \mathrm{~kg}$ untuk satu siklus produksi, sedangkan rata - rata perhari produksi yaitu $4.35 \%$ atau sekitar $10.59 \mathrm{~kg}$ perhari. Dilihat dari rata - rata produksi perhari, petani bisa menghentikan panen pada hari ke 19 . Pada hari ke 19 produksi jamur hanya $6.87 \mathrm{~kg}$ atau sekitar $2.89 \%$, jumlah tersebut sudah sangat menurun dari hari sebelumnya yaitu sebanyak $11.43 \mathrm{~kg}$. Penurunan tersebut terjadi pada dua kumbung yaitu kumbung 1 dan 4. Pada kumbung satu terjadi penurunan sebesar $10.7 \mathrm{~kg}$, sedangkan pada kumbung empat penurunan sebesar $5.2 \mathrm{~kg}$. Pada kumbung 2 dari hari ke 18 sampai hari ke 19 terjadi peningkatan sebesar $2.2 \mathrm{~kg}$. Pada hari ke 20 rata - rata produksi jamur meningkat sebesar $7.9 \mathrm{~kg}$ menjadi $14.77 \mathrm{~kg}$. Peningkatan pada hari ke 20 terjadipada ketiga kumbung. Kumbung satu mengalami peningkatan sebanyak $21.1 \mathrm{~kg}$, sedangkan pada kumbung 2 peningkatan hanya 2 $\mathrm{kg}$ dan pada kumbung 4 peningkatan sebesar 0.9 $\mathrm{kg}$.

Jamur merang kualitas Super yang didapat sebanyak $207.11 \mathrm{~kg}$ atau $87.23 \%$ dari total jamur yang dipanen, sedangkan jamur kualitas BS sebanyak $30.31 \mathrm{~kg}$ atau sekitar $12.77 \%$ dari total jamur. Rata - rata produksi jamur merang tertinggi terdapat pada hari ke 16 yaitu sebesar $16.67 \mathrm{~kg}$ total jamur Super dan BS. Rata - rata jamur merang kualitas super paling tinggi juga terdapat pada hari ke 16 yaitu sebesar $14.77 \mathrm{~kg}$, sedangkan rata - rata tertinggi untuk jamur merang kualitas BS terdapat pada hari ke 3 sebesar $2.33 \mathrm{~kg}$. Tidak terdapat perbedaan yang berarti terhadap bobot jamur merang yang dipanen pada pagi hari maupun sore hari, baik untuk jamur merang kualitas super maupun jamur merang kualitas BS.

Produksi jamur merang mencapai $25 \%$ pada hari ke $6.50 \%$ pada hari ke 12 sedangkan mencapai $75 \%$ pada hari ke 16 . Pada panen hari ke 18 , produksi jamur merang sudah mencapai $80 \%$ dari produksi total keseluruhan. Panen hari pertama jamur merang pada kelompok tani Mitra Usaha selalu dilakukan pada sore hari, hal tersebut dilakukan karena dipagi hari kondisi jamur didalam kumbung belum siap panen, sedangkan berhentinya masa panen biasanya berdasarkan jumlah tubuh buah jamur didalam kumbung. 
Hasil analisis statistik untuk bobot jamur Super menunjukkan hampir pada setiap panen atau selama 21 hari, kecuali pada hari ke 4, 5, 10, $11,12,18$ dan 19 hasil yang didapat rak 4 dan 5 hampir selalu berbeda nyata dengan rak 1 . Bobot jamur Super terbesar didapat pada hari pertama dan pada rak 4 sebelah kiri yaitu sebesar 498,8 a gram atau $99.8 \%$ dari 500 gram sampel jamur.

Tingkatan rak juga mempengaruhi jumlah jamur BS yang didapat. Rak yang terletak di bawah yaitu rak 1 selalu menghasilkan BS terbanyak dibandingkan tingkatan rak diatasnya. Analisis statistik untuk bobot jamur BS menunjukkan pada rak 1 hampir selalu berbeda nyata dengan rak 4. Rata - rata jamur BS terbanyak didapat pada hari ke 17 pada rak 1 sebelah kanan yaitu sebesar 32.30a gram atau $6.5 \%$ dari 500 gram sampel jamur.

\section{Bobot harian jamur merang per rak}

Setiap kumbung memiliki 10 rak tempat tumbuh jamur yang dibagi 5 rak dikiri dan 5 rak dikanan yang disusun secara bertingkat. Setiap rak diambil sampel secara acak sebanyak 500 gram dan dilakukan selama masa panen. Pengambilan 500 gram ditujukan untuk mengetahui pada tingkatan rak ke berapa dan letak rak yang mana yang paling berpotensi menghasilkan jamur kualitas BS dengan menggunakan uji DMRT. Ulangan diambil dari jumlah kumbung (3), tingkatan rak sebagai taraf (5) hari (23) dan tata letak rak (2) sebagai perlakuan dengan $\alpha=$ $5 \%$.Data yang didapat dari hari ke 1 sampai ke 21 didapat dari rata - rata kumbung 1, 2 dan 4. Data yang didapat pada hari ke 22 dan 23 hanya didapat dari kumbung 1. Kumbung 3 tidak termasuk dalam data dikarenakan terjadi gagal panen.

Jumlah BS yang didapat pada rak memiliki nilai paling tinggi yaitu 456.3 gram pada rak kiri dan 413.2 gram pada rak kanan. Jumlah BS terendah terdapat pada rak ke 4 yaitu sebanyak 220.8 gram pada rak sebelah kiri dan 203.6 gram pada rak sebelah kanan. Dari kelima tingkatan rak pada setiap kumbung dapat dilihat bahwa rak sebelah kiri baik pada rak ke 1 atau paling bawah sampai rak ke 5 atau rak paling atas, letak rak sebelah kiri menghasilkan jamur merang berkualitas BS lebih banyak dibandingkan rak sebelah kanan (Gambar 9).

Tabel 3 menunjukan jumlah jamur yang tidak layak pasar (BS) dalam 500 gram sampel yang diambil secara acak. Jumlah BS yang paling banyak terdapat pada rak satu atau rak paling bawah. Dapat dilihat dari hasil yang didapatkan yaitu sebanyak 869.5 gram atau 29\% dari seluruh total jamur BS yang didapatkan. Untuk keempat rak lainnya yaitu rak dua sebanyak $23 \%$, rak tiga $19 \%$, rak empat $14 \%$ dan rak lima sebanyak 16\%.Tingkatan rak memiliki pengaruh nyata terhadap produksi jamur merang. Rak 1 hampir selalu memberikan nilai terbesar untuk jamur kualitas BS.Pergerakan jumlah BS pada setiap kumbung semakin atas posisi rak, jumlah BS yang didapat semakin menurun. Hal tersebut diduga disebabkan karena pada rak satu yaitu rak paling bawah diduga tingkat kelembaban lebih besar dibanding dengan keempat rak yang ada diatasnya yaitu rak dua, tiga, empat, dan lima. Kelembaban tersebut menyebabkan pertumbuhan jamur menjadi lebih cepat, sehingga banyak BS yang didapatkan. Jumlah BS terbesar didapat pada hari ke 17 di tingkatan rak paling bawah yaitu sebesar 58.3 gram, sedangkan pada tingkatan rak yang lainnya tidak ada yang melebihi 40 gram selama masa panen atau 23 hari. Pada hari ke 6 jumlah BS terbanyak didapat pada rak 3 sebesar 17 gram pada rak kiri dan 19 gram pada rak kanan (Tabel 3). Pada beberapa hari tertentu tidak terdapat perbedaan nyata yaitu pada hari ke $3,4,10,11$, 12, 18, dan 19.

Bobot rata - rata jamur kualitas super jugadiambil dari sampel yang sama untuk jamur BS. Hasil analisis DMRT tingkatan rak juga mempengaruhi hasil yang didapat.Hasil rata - rata jamur super tertinggi terdapat pada rak 4 sebesar 22575,6 gram atau sebesar $20.15 \%$ dari total keseluruhan jamur super yang diamati. Hasil yang didapat keempat rak lainnya yaitu rak lima sebesar $20.13 \%$, rak tiga $20.03 \%$, rak dua $19.93 \%$, dan rak satu sebesar $19.75 \%$. Hasil jamur merang kualitas super berbanding terbalik dengan jumlah yang didapat jamur kualitas BS. Hasil terbesar rata - rata jamur merang kualitas super terdapat pada tingkat atas yaitu pada rak 4. Hari pertama pada rak 4 memiliki hasil terbesar yaitu sebesar 993.3 gram dari total rak kanan sebesar 494.5 gram dan kiri sebesar 498.8 gram (Tabel 4). Pada hari ke 4, 5, 10, 11, 12, 18 dan 19 tidak terdapat perbedaan nyata untuk seluruh tingkatan rak. Jumlah super yang didapat selama 23 hari selalu diatas $95 \%$ dari 500 gram sampel yang diambil. 


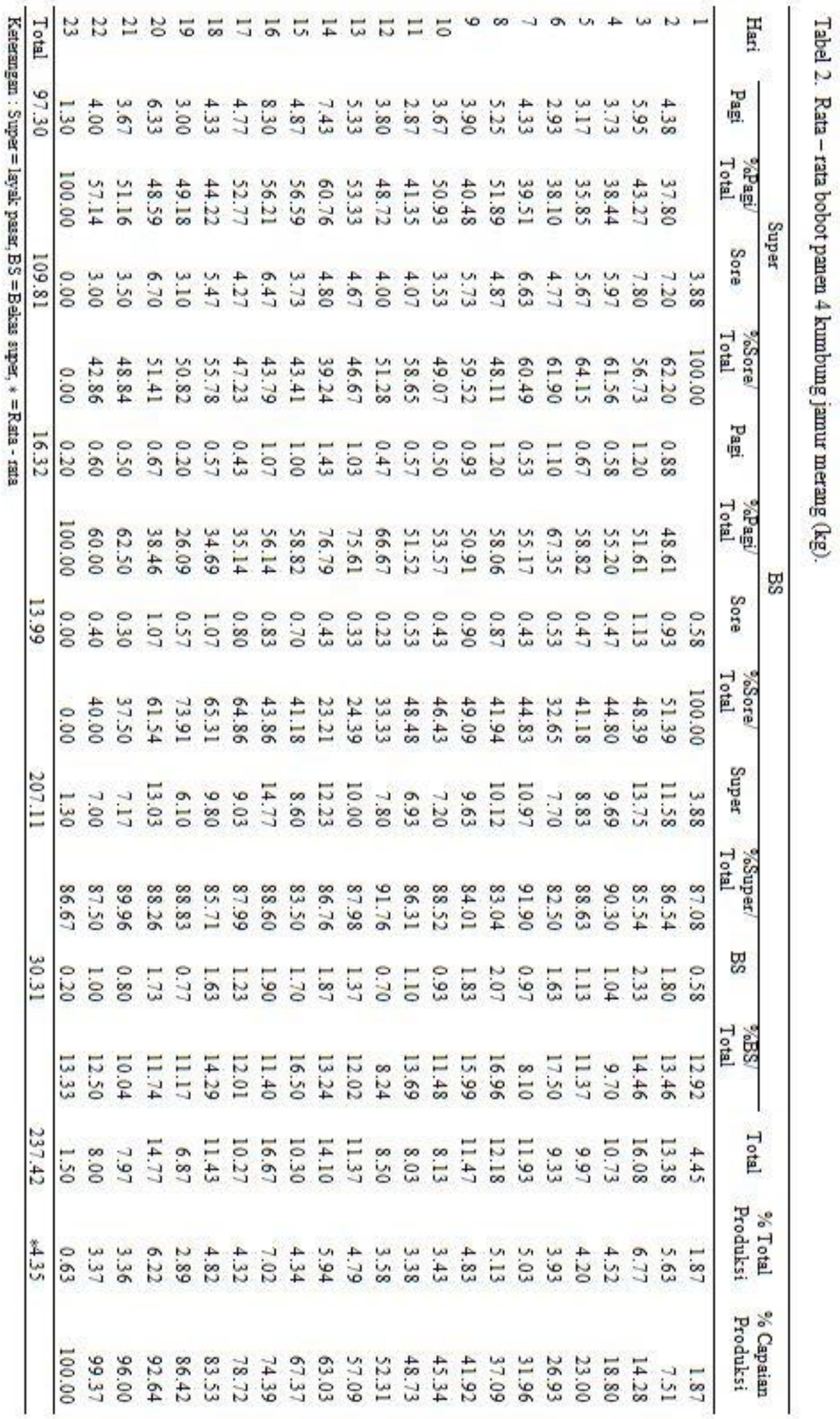




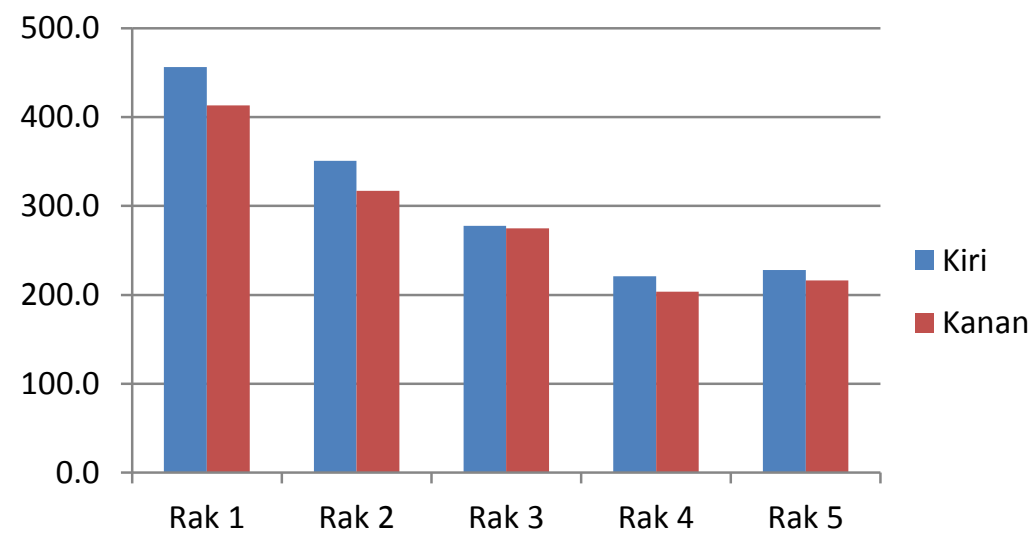

Gambar 2. Perbandingan bobot jamur BS berdasarkan tingkatan dan tata letak rak

Tabel 3. Rata - rata bobot jamur kualitas Super dalam 500 gram dari keempat kumbung (gram)

\begin{tabular}{|c|c|c|c|c|c|c|c|c|c|c|}
\hline \multirow{2}{*}{ Hari } & \multicolumn{2}{|c|}{ Rak 1} & \multicolumn{2}{|c|}{ Rak 2} & \multicolumn{2}{|c|}{ Rak 3} & \multicolumn{2}{|c|}{ Rak 4} & \multicolumn{2}{|c|}{ Rak 5} \\
\hline & Kiri & Kanan & Kiri & Kanan & Kiri & Kanan & Kiri & Kanan & Kiri & Kanan \\
\hline 1 & $489.3 b$ & $483.3 b$ & $488.3 b$ & $481.8 b$ & $489.0 \mathrm{~b}$ & $488.3 b$ & $498.8 \mathrm{a}$ & $494.5 \mathrm{a}$ & 493.8ab & 491.3ab \\
\hline 2 & $488.3 b$ & $474.5 b$ & $486.0 \mathrm{ab}$ & $484.0 \mathrm{ab}$ & $484.8 \mathrm{ab}$ & $487.0 \mathrm{ab}$ & $490.0 \mathrm{a}$ & $491.3 \mathrm{a}$ & $492.0 \mathrm{a}$ & $490.8 \mathrm{a}$ \\
\hline 3 & $482.5 c$ & $484.8 \mathrm{c}$ & $485.5 \mathrm{ab}$ & $495.5 \mathrm{ab}$ & $486.8 b c$ & $490.0 \mathrm{bc}$ & $493.8 \mathrm{a}$ & $497.0 \mathrm{a}$ & $492.8 \mathrm{ab}$ & $492.3 \mathrm{ab}$ \\
\hline 4 & $487.3 \mathrm{a}$ & $478.7 \mathrm{a}$ & $485.3 \mathrm{a}$ & $479.3 \mathrm{a}$ & $490.0 \mathrm{a}$ & $483.7 \mathrm{a}$ & $488.0 \mathrm{a}$ & $489.3 \mathrm{a}$ & $485.0 \mathrm{a}$ & $484.0 \mathrm{a}$ \\
\hline 5 & $479.7 \mathrm{a}$ & $482.7 \mathrm{a}$ & $483.7 \mathrm{a}$ & $478.3 \mathrm{a}$ & $484.7 \mathrm{a}$ & $492.0 \mathrm{a}$ & $491.7 \mathrm{a}$ & $491.3 \mathrm{a}$ & $489.7 \mathrm{a}$ & $487.7 \mathrm{a}$ \\
\hline 6 & $477.3 b$ & 493.0a & $488.3 \mathrm{ab}$ & 483.0ab & $482.7 b$ & $481.0 \mathrm{~b}$ & $493.3 \mathrm{a}$ & $491.7 \mathrm{a}$ & $491.7 \mathrm{a}$ & $492.7 \mathrm{a}$ \\
\hline 7 & $475.7 b$ & $487.7 b$ & 483.0ab & $486.3 \mathrm{ab}$ & $483.7 \mathrm{ab}$ & $485.7 \mathrm{ab}$ & $489.3 \mathrm{a}$ & 493.0a & $484.0 \mathrm{ab}$ & 491.7ab \\
\hline 8 & $475.7 b$ & $473.3 b$ & $480.7 \mathrm{ab}$ & $483.0 \mathrm{ab}$ & $487.0 \mathrm{a}$ & $490.0 \mathrm{a}$ & $486.0 \mathrm{ab}$ & 485.0ab & $490.0 \mathrm{a}$ & $491.3 \mathrm{a}$ \\
\hline 9 & $479.7 b$ & $481.7 b$ & $488.3 b$ & $480.0 \mathrm{~b}$ & $497.7 \mathrm{a}$ & $493.7 \mathrm{a}$ & $496.0 \mathrm{a}$ & 484.7ab & $485.0 \mathrm{ab}$ & 491.7ab \\
\hline 10 & $490.7 \mathrm{a}$ & $483.3 \mathrm{a}$ & $488.7 \mathrm{a}$ & $481.3 \mathrm{a}$ & 494.0a & $487.7 \mathrm{a}$ & $487.0 \mathrm{a}$ & $500.0 \mathrm{a}$ & $490.3 a$ & $494.3 \mathrm{a}$ \\
\hline 11 & $481.3 \mathrm{a}$ & 494.0a & $484.3 \mathrm{a}$ & $482.7 \mathrm{a}$ & $490.7 \mathrm{a}$ & $493.3 \mathrm{a}$ & $485.7 \mathrm{a}$ & 494.0a & $491.3 \mathrm{a}$ & $490.7 \mathrm{a}$ \\
\hline 12 & $482.0 \mathrm{a}$ & $490.0 \mathrm{a}$ & $482.7 \mathrm{a}$ & 489.0a & 494.3a & $488.0 \mathrm{a}$ & $489.7 \mathrm{a}$ & $487.7 \mathrm{a}$ & $492.3 \mathrm{a}$ & $490.0 \mathrm{a}$ \\
\hline 13 & $478.7 b$ & $480.7 b$ & $482.0 \mathrm{ab}$ & $494.3 \mathrm{ab}$ & $488.3 \mathrm{ab}$ & $485.0 \mathrm{ab}$ & $494.7 \mathrm{a}$ & $497.3 \mathrm{a}$ & $490.3 a$ & $494.7 \mathrm{a}$ \\
\hline 14 & $479.7 \mathrm{c}$ & $482.0 \mathrm{c}$ & $485.3 \mathrm{ab}$ & 495.0a & $482.3 b c$ & $485.3 \mathrm{bc}$ & $491.3 \mathrm{a}$ & $496.7 \mathrm{a}$ & $484.7 \mathrm{ab}$ & $495.0 \mathrm{a}$ \\
\hline 15 & $472.7 b$ & $479.7 b$ & $482.0 \mathrm{a}$ & 496.0a & $491.7 \mathrm{a}$ & $482.7 \mathrm{a}$ & $484.7 \mathrm{a}$ & $493.3 \mathrm{a}$ & $491.7 \mathrm{a}$ & $485.7 \mathrm{a}$ \\
\hline 16 & $468.3 b$ & $476.3 b$ & $486.3 \mathrm{a}$ & 483.0a & $480.7 \mathrm{a}$ & $493.3 \mathrm{a}$ & 489.0a & $486.3 \mathrm{a}$ & $485.0 \mathrm{a}$ & $488.0 \mathrm{a}$ \\
\hline 17 & $474.0 \mathrm{~b}$ & $467.7 b$ & $489.3 \mathrm{a}$ & $478.0 \mathrm{a}$ & $481.3 \mathrm{a}$ & $488.7 \mathrm{a}$ & $492.3 \mathrm{a}$ & $482.7 \mathrm{a}$ & $491.7 \mathrm{a}$ & $490.3 \mathrm{a}$ \\
\hline 18 & $482.0 \mathrm{a}$ & $492.7 \mathrm{a}$ & $478.0 \mathrm{a}$ & 489.0a & $488.0 \mathrm{a}$ & $486.3 \mathrm{a}$ & $488.7 \mathrm{a}$ & $487.0 \mathrm{a}$ & $490.0 \mathrm{a}$ & $486.0 \mathrm{a}$ \\
\hline 19 & $486.0 \mathrm{a}$ & $487.7 \mathrm{a}$ & $482.3 \mathrm{a}$ & $485.0 \mathrm{a}$ & $492.0 \mathrm{a}$ & $487.3 \mathrm{a}$ & $486.7 \mathrm{a}$ & $493.3 \mathrm{a}$ & $487.7 \mathrm{a}$ & $489.7 \mathrm{a}$ \\
\hline 20 & $475.7 b$ & $471.0 \mathrm{~b}$ & $488.3 \mathrm{a}$ & $481.7 \mathrm{a}$ & $482.7 \mathrm{a}$ & $488.3 \mathrm{a}$ & 488.0a & $487.7 \mathrm{a}$ & $489.3 \mathrm{a}$ & $485.0 \mathrm{a}$ \\
\hline 21 & $483.3 b$ & $483.3 b$ & $488.7 \mathrm{ab}$ & $484.7 \mathrm{ab}$ & $491.0 \mathrm{a}$ & 485.0ab & $494.7 \mathrm{a}$ & $486.7 \mathrm{a}$ & $494.0 \mathrm{a}$ & $490.0 \mathrm{a}$ \\
\hline 22 & 476.0 & 479.0 & 474.0 & 492.0 & 500.0 & 490.0 & 488.0 & 500.0 & 490.0 & 500.0 \\
\hline 23 & 478.0 & 480.0 & 488.0 & 500.0 & 479.0 & 493.0 & 492.0 & 486.0 & 500.0 & 491.0 \\
\hline
\end{tabular}

Keterangan: Angka-angka pada baris yang sama yang diikuti oleh huruf yang sama tidak berbeda nyata pada taraf uji $\alpha=5 \%$ (DMRT)

\section{Pemasaran}

Alur pemasaran yang terjadi dalam kelompok tani melalui dua tengkulak sebelum jamur yang diproduksi menyebar dipasaran. Jamur yang dijual ke tengkulak hanya jamur yang berkualitas super saja, sedangkan yang tidak layak pasar (BS) biasanya petanimenjual langsung kepada tetangga atau menitipkannya pada pedagang keliling didaerah tersebut. Jamur BS biasa dijual dengan harga Rp16 000,00/kg, sedangkan jamur super dijual kepada tengkulak pertama dengan harga Rp22 000,00/kg. Dari tengkulak pertama jamur dijual kembali ke tengkulak kedua dengan harga Rp28 000,00/kg yang kemudian oleh tengkulak dua dijual

Faisal Radjab Munawar dan Juang Gema Kartika 
dipasaran didaerah Jabodetabek dengan harga pasar kurang lebih Rp35 000,00 - Rp40 000,00 $/ \mathrm{kg}$.

Jamur BS selain dijual dalam bentuk jamur segar, biasanya diolah lagi oleh ibu - ibu dari kelompok tani tersebut menjadi cilok jamur. Dengan olahan jamur tersebut para ibu - ibu mendapatkan untung yang cukup banyak disbanding hanya menjual dalam bentuk jamur segar saja. Dalam satu kilo jamur jika diolah menjadi cilok bisa menghasilkan 100 cilok dengan bahan bahan untuk membuat cilok yang tidak terlalu mahal seperti, tepung aci, bawang merah dan lain lain membuat keuntungan yang diperoleh bertambah. Harga cilok yang dijual yaitu $\mathrm{Rp500,00/} \mathrm{cilok} \mathrm{dengan} \mathrm{harga} \mathrm{produksi} \mathrm{satu}$ cilok sekitar Rp300,00/ cilok memberikan keuntungan yang cukup besar. Jika dibandingkan dengan hanya menjual dalam bentuk jamur segar.

\section{Analisis Usaha Tani}

Dengan asumsi waktu satu siklus panen yaitu 1,5 bulan dengan rata - rata produktivitas yaitu $200 \mathrm{~kg} /$ musim tanam. Biaya produksi yang harus dikeluarkan petani yaitu Rp2 307 188,00 dengan harga jual jamur sebesar Rp22 000,00 / kg maka penerimaan hasil jual sebesar Rp4 400 000,00 . Dengan demikian keuntungan yang didapatkan petani sebanyak Rp2 092 813,00. Dengan asumsi analisis usaha diatas, kelompok tani "Mitra Usaha" layak untuk terus dijalankan karena keuntungan yang diperoleh petani bisa menutupi biaya produksi. Selain dilihat dari keuntungan yang didapat, kelayakan suatu usaha juga dapat dilihat dari nilai $\mathrm{R} / \mathrm{C}$ rasio apabila nilai yang didapat lebih dari 1. Dilihat dari asumsi analisis usaha diatas didapatkan nilai $\mathrm{R} / \mathrm{C}$ rasio sebesar 1,91 (>1). Dengan nilai R/C yang lebih besar dari 1 menyatakan kelompok tani "Mitra Usaha" layak untuk terus berjalan. BEP untuk harga didapat sebesar Rp11 536,00 yang artinya dengan jumlah jamur $200 \mathrm{~kg}$ per kumbung dan harga jamur Rp11 536,00 per kg, maka petani tidak mendapatkan untung dan tidak rugi. BEP volume produksi didapat sebesar $105 \mathrm{~kg}$, artinya dengan harga jamur Rp22 000,00 per kg, petani hanya memerlukan $105 \mathrm{~kg}$ jamur untuk tidak mengalami kerugian.

\section{KESIMPULAN}

Kegiatan penelitian di kelompok tani Mitra Usaha meningkatkan kemampuan teknis dan kemampuan manajemen penulis, sehingga dapat menjadi ilmu tambahan untuk dunia kerja. Produksi jamur merang di kelompok tani Mitra Usaha cukup bagus dan layak untuk terus berproduksi. Hal tersebut dibuktikan pada analisis usaha tani perbandingan $\mathrm{R} / \mathrm{C}$ rasio yang didapat sebesar 1.91. Angka tersebut melebihi standar minimal R/C rasio yaitu 1 yang menjadi pembanding layak atau tidaknya suatu usaha. Produksi jamur merang mencapai $80 \%$ pada panen hari ke- 18. Rata - rata produksi satu kumbung mampu mencapai $237.42 \mathrm{~kg}$ selama satu siklus. Secara umum, rak yang lebih di atas, menghasilkan jamur Super yang lebih banyak dibanding rak yang terletak di bawah. Rak 4 dan 5 memberi hasil jamur Super lebih baik daripada rak 1. Berdasarkan analisis statistik untuk jamur BS, tingkatan rak berpengaruh sangat nyata terhadap bobot jamur merang, sedangkan untuk jamur super kumbung dan rak berpengaruh sangat nyata.

\section{DAFTAR PUSTAKA}

Agrina. 2007. Bisnis Jamur Bikin Tergiur. [Internet] [diunduh 2015 Okt 08] tersedia pada http://www.agrina-online.com/show _article.php? aid=1009.

Agromedia. 2009. Buku Pintar Bertanam Jamur Merang. Agromedia Pustaka, Jakarta.

Climate Data. 2015. Data iklim untuk kota - kota di seluruh dunia.. [Internet] [diunduh 2015 Des 24] tersedia pada http://id. climatedata.org/location/764269/.

[KEMENTAN] Kementrian Pertanian. 2015a. Produksi jamur setahun di Indonesia periode 2011 - 2014 [Internet] [diunduh 2015 Des 20] http://aplikasi. pertanian.go.id/bdsp/hasil_kom.asp.

[KEMENTAN] Kementrian Pertanian. 2015b. Konsumsi jamur setahun perkapita di Indonesia periode 2009 - 2014. [Internet] [diunduh 2015 Des 20] tersedia pada http://aplikasi2.pertanian. go.id/konsumsi/tampil_susenas2.php

[KEMENTAN] Kementrian Pertanian. 2015c. Produksi jamur setahun perProvinsi di Indonesia periode 2010 - 2013. [Internet] [diunduh 20 Des 2015] tersedia padahttp://aplikasi.pertanian. go.id/bdsp/hasil_lok.asp 
[KEMENTAN] Kementrian Pertanian. 2015d. Produksi jamur setahun perKabupaten di Jawa Barat periode 2010 - 2013. [Internet] [diunduh 2015 Des 20] http://aplikasi.pertanian.go.id/bdsp/hasil_lo k.asp.

Mayun I.A. 2007. Pertumbuhan jamur merang (Volvariella volvaceae) pada berbagai media tumbuh. J. Agritrop. (26)3: 124 128.

Oktaviana T. 2013. Analisis pendapatan usahatani dan tataniaga jamur merang (Volvariella volvaceae) di Desa Gempol Kolot, Kecamatan Banyusari, Kabupaten Karawang.Skripsi. Institut Pertanian Bogor. Bogor.
Sinaga M.S. 2012. Budi Daya Jamur Merang. Penebar Swadaya, Jakarta

Trubus. 2012. Jamur Merang. Penebar Swadaya, Jakarta.

Yuliani F. 2009. Pertumbuhan dan produksi jamur merang (Volvariella volvaceae) yang ditanam pada media jerami, blotong dan ampas tebu dengan berbagai frekwensi penyiraman. J. Sains dan Teknologi 2 (1)

Zuyasna., Nasution M., Fitriani D. 2011. Pertumbuhan dan hasil jamur merang akibat perbedaan media tanam dan konsentrasi pupuk super A-1. J. Floratek. 6:92-103 